\title{
PENGARUH KONDISI PSIKIS PEGAWAI, KOMPENSASI, DAN LINGKUNGAN KERJA TERHADAP KUALITAS PELAYANAN PEGAWAI UPTD PUSKESMAS GETASAN KABUPATEN SEMARANG
}

\author{
Oleh : \\ Handayono ${ }^{1)}$, Hardi Utomo ${ }^{2)}$ \\ STIE AMA Salatiga
}

\begin{abstract}
Abstrak
Penelitian tentang pengaruh kondisi psikis, kompensasi, dan lingkungan kerja terkait dengan masalah kualitas pelayanan di Puskemas Getasan selama ini belum pernah dilakukan. Hal inilah yang mendorong peneliti untuk melakukan penelitian tentang hal tersebut. Sebab menurut hasil pengamatan peneliti rendahnya kualitas pelayanan yang diberikan oleh pegawai di puskesmas tersebut diduga karena dipicu oleh ketiga faktor tersebut.

Tujuan dari penelitian ini adalah untuk mengetahui pengaruh kondisi psikis pegawai, kompensasi yang diterima pegawai, dan lingkungan kerja pegawai secara parsial maupun simultan terhadap kualitas pelayanan Pegawai UPTD Puskesmas Getasan Kabupaten Semarang.

Tipe penelitian dalam penulisan skripsi ini adalah eksplanatori. Data primer diperoleh dengan membagikan kuesioner kepada responden yang berjumlah 50 orang pegawai, sedang data sekunder diperoleh dari catatan administrasi Kantor UPTD Puskesmas Getasan Kabupaten Semarang. Alat analisis data yang digunakan adalah regresi linier berganda.

Hasil analisis regresi menunjukkan: 1) Persamaan regresi linier berganda hasil penelitian, yaitu $Y=3,262+0,191 X 1+0,159 X 2+0,538 X 3$, 2) Ada pengaruh signifikan kondisi psikis pegawai terhadap kualitas pelayanan Pegawai UPTD Puskesmas Getasan Kabupaten Semarang, dibuktikan nilai t-hitung $(2,611)>$ nilai ttabel (2,013), 3) Ada pengaruh signifikan kompensasi terhadap kualitas pelayanan Pegawai UPTD Puskesmas Getasan Kabupaten Semarang, dibuktikan nilai t-hitung (2,638) > nilai t-tabel (2,013), 3) Ada pengaruh signifikan lingkungan kerja terhadap kualitas pelayanan Pegawai UPTD Puskesmas Getasan Kabupaten Semarang, dibuktikan nilai t-hitung (6,311) > nilai t-tabel (2,013), 4) Ada pengaruh signifikan kondisi psikis pegawai, kompensasi yang diterima pegawai, dan lingkungan kerja pegawai secara simultan terhadap kualitas pelayanan Pegawai UPTD Puskesmas Getasan Kabupaten Semarang, dibuktikan nilai F-hitung $(38,110)>$ F-tabel $(2,81), 5)$ Nilai Adjusted $R$ Square hasil analisis regresi adalah 69,40\%, artinya variasi variabel dependen (Kualitas Pelayanan $(Y)$ ) yang dapat dijelaskan oleh variasi dari ketiga variabel independen, yaitu: Kondisi Psikis $\left(X_{1}\right)$, Kompensasi $\left(X_{2}\right)$, dan Lingkungan Kerja $\left(X_{3}\right)$ adalah sebesar 69,40\%, sedangkan sisanya 30,60\% dijelaskan oleh variabel-variabel lain yang tidak diteliti.

Simpulan penelitian ini, yaitu: 1) Hipotesis I, II, dan III diterima, ditunjukkan nilai t-hitung masing-masing variabel $>$ nilai t-tabel $(2,013), 2)$ Hipotesis IV penelitian diterima, ditunjukkan nilai F-hitung $(38,110)>F$-tabel $(2,81)$.

Saran dalam penelitian ini adalah: 1) Perlu menambah watt lampu ruangan yang dinilai masih kurang terang, perlu ditambah tenaga-tenaga honorer untuk bagian kebersihan, 2) Melakukan evaluasi secara berkala terhadap kinerja para pegawainya, selain itu melakukan diklat pada pegawai-pegawai, 3) Masalah beban kerja juga perlu dipertimbangkan dalam pemberian kompensasi.
\end{abstract}

Kata Kunci: Kondisi Psikis, Kompensasi, Lingkungan Kerja, Kualitas Pelayanan 


\section{PENDAHULUAN}

Teknologi yang semakin maju pada era globalisasi saat ini mendorong perkembangan jasa berkembang dengan pesat. Sektor jasa merupakan salah satu sektor yang akan memainkan peranan penting dalam era globalisasi ini, untuk itu sektor jasa seperti juga sektor lainnya harus semakin terspesialisasi dalam proses produksi yang dilakukannya, salah satu hal yang harus diperhatikan oleh perusahaan/badan usaha/organisasi yang bergerak dalam jasa pelayanan yaitu dengan memberikan pelayanan yang terbaik kepada konsumen/pengguna jasa.

Salah satu sektor jasa yang penting bagi masyarakat adalah pelayanan jasa yang bergerak di bidang kesehatan salah satunya adalah Puskesmas. Pusat Kesehatan Masyarakat (Puskesmas) adalah salah satu sarana pelayanan kesehatan masyarakat yang amat penting di Indonesia. Puskesmas adalah unit pelaksana teknis Dinas Kesehatan Kabupaten/kota yang bertanggung jawab menyelenggarakan pembangunan kesehatan di satu atau sebagian wilayah kecamatan (Kepmenkes No. 128 Tahun 2004). Puskesmas menjadi tempat pelayanan kesehatan yang berhubungan langsung dengan masyarakat yang bertanggungjawab dalam penyelenggaraan pelayanan kesehatan masyarakat dengan mutu yang baik dan dengan biaya yang terjangkau oleh masyarakat (Hartono, 2010:55).

Sebagai pusat pelayanan kesehatan yang sangat diandalkan oleh masyarakat maka volume pelayanan medis dan non medis Puskesmas sangatlah padat. Sedangkan Sumber Daya Manusia (SDM) Puskesmas relatif terbatas sehingga kebutuhan pelayanan untuk setiap pegawai Puskesmas terhadap masyarakat yang memanfaatkan jasa pelayanan Puskesmas sangatlah tinggi. Melihat intensitas kepadatan pelayanan tersebut tentunya dibutuhkan beberapa faktor yang perlu dipenuhi oleh pihak manajemen Puskesmas agar pegawai mampu menampilkan kualitas pelayanan yang sesuai dengan harapan masyarakat, diantaranya adalah menjaga kondisi psikis pegawai, memberikan kompensasi yang memadai bagi setiap pegawai, dan menciptakan lingkungan kerja yang mendukung.

Berbicara tentang kualitas pelayanan, Tjiptono (2006:260) mendefinisikannya sebagai tingkat keunggulan (excellence) yang diharapkan dan pengendalian atas keunggulan tersebut untuk memenuhi keinginan pelanggan (Wyckof dalam Tjiptono, 2006:260). Sementara kualitas pelayanan itu sendiri dapat dinilai dari beberapa 
dimensi, seperti: bukti fisik (tangible), keandalan (reability), daya tanggap (responsiveness), jaminan (assurance) dan empati (empaty) (Zeithaml, et al dalam Lupiyoadi, 2009:148). Sebagai organisasi publik yang bertanggung jawab dalam memenuhi kebutuhan kesehatan masyarakat, tentunya pihak puskesmas dituntut untuk mampu menampilkan kualitas pelayanan yang bermutu sebagai sebuah bentuk pencapaian atas kinerjanya. Kondisi tersebut dapat diciptakan manajemen puskesmas dengan menjaga kondisi psikis (psikologis) pegawainya, memberikan kompensasi yang layak kepada pegawainya, dan mampu menciptakan lingkungan kerja yang baik.

Kondisi psikis atau faktor psikologis adalah faktor yang berhubungan dengan kejiwaan pegawai. Kondisi psikis pegawai ditunjukkan oleh kemampuan mengelola emosi pegawai yang meliputi dimensi intelegensi, bakat, minat, kepribadian, motivasi serta kesesuaian pendidikan dengan pekerjaan (As'ad, 2006:115). Dalam jasa pelayanan kususnya dalam hal ini Puskesmas Getasan dengan kondisi pegawai yang bermacam-macam karakter, baik itu tingkat intelegensi, bakat, minat, kepribadian, motivasi, dan pendidikan diharapkan mampu untuk mengatasi segala kesulitan dalam melaksanakan pelayanan pada masyarakat.

Faktor yang kedua yang mempengaruhi kualitas pelayanan yang diberikan pegawai adalah pemberian kompensasi yang sesuai (Wardana, 2006). Kesesuaian pemberian kompensasi menjamin perasaan puas, dan para pekerja tetap termotivasi, serta efektivitas bagi organisasi secara keseluruhan (Gomes, 2006:129). Panggabean (2002:75) menyatakan bahwa kompensasi acapkali juga disebut sebagai penghargaan dan dapat didefinisikan sebagai setiap bentuk penghargaan yang diberikan kepada pegawai sebagai balas jasa atas kontribusi yang mereka berikan kepada organisasi. Dijelaskan lebih lanjut oleh Simamora (2006:540), pada saat dikelola secara benar, kompensasi membantu organisasi mencapai tujuan-tujuannya serta memperoleh, memelihara dan mempertahankan tenaga kerja yang produktif. Begitu pentingnya faktor kompensasi bagi pegawai, maka sudah sewajarnya jika pihak puskesmas menciptakan sistem sedemikian rupa agar kompensasi yang diberikan kepada pegawainya memenuhi berbagai persyaratan, yaitu : kompensasi harus dapat memenuhi kebutuhan minimal, kompensasi harus dapat meningkat, kompensasi harus dapat menimbulkan semangat dan kegairahan kerja, kompensasi harus adil, kompensasi tidak boleh bersifat statis, komposisi dari kompensasi yang diberikan. 
Faktor yang ketiga yang mempengarui kualitas pelayanan adalah faktor lingkungan kerja. Lingkungan kerja merupakan segala sesuatu yang ada disekitar pekerja sewaktu menjalankan tugas yang dibebankan. Lingkungan kerja adalah keadaan di sekitar tempat kerja pada waktu pegawai melakukan pekerjaannya. Keadaan tersebut dapat mempengaruhi kesejahteraan pegawai sehingga pegawai akan berusaha untuk menghasilkan sesuatu. Lingkungan kerja yang baik akan membawa pengaruh yang baik kepada para pegawai, pimpinan, dan hasil pekerjaannya (Khusnul, 2010). Ditambahkan pula oleh As'ad (2006:104), bahwa rasa aman akan suasana kerja yang mampu mendorong pegawai untuk lebih berdedikasi tinggi dalam menyelesaikan tugas yang diberikan oleh pimpinan baik suasana aman sebelum kerja, saat kerja maupun setelah kerja. Kondisi kerja yang aman semacam ini, serta didukung rekan kerja yang dapat diajak untuk bekerjasama dalam berbagai aktifitas merupakan keinginan dari setiap pegawai di setiap instansi atau organisasi. Dengan situasi semacam itu diharapkan para pegawai dapat bekerja secara maksimal dan senang terhadap pekerjaan yang dilakukannya sehingga kinerja mereka meningkat yang ditandai dengan output pelayanan yang lebih berkualitas.

Salah satu Puskesmas di Wilayah Kabupaten Semarang adalah UPTD Puskesmas Getasan. Puskesmas ini tepatnya berada di Jalan Raya Getasan No. 09 Kecamatan Getasan Kabupaten Semarang. UPTD Puskesmas Getasan itu sendiri mempunyai beberapa unit besar, yaitu: BP (Balai Pengobatan), BP Gigi, dan BKIA (Balai Kesehatan Ibu dan anak), Laboratorium dan Rawat Inap, serta Konsultasi Gizi. Pada dasarnya UPTD Puskesmas Getasan melayani masyarakat di wilayah Kecamatan Getasan dan sekitarnya. Pelayanan rawat jalan dibuka mulai hari Senin sampai dengan Sabtu, sedangkan untuk rawat Inap buka tiap hari.

Sebagai Puskesmas yang dinilai menyediakan pelayanan kesehatan yang beragam, keberadaan Puskesmas Getasan menjadi tempat rujukan utama bagi masyarakat di wilayah tersebut, sehingga aktivitas sehari-hari di puskemas tersebut terlihat sangat padat. Selain karena faktor tersedianya pelayanan kesehatan yang beragam, kepadatan aktivitas pelayanan kesehatan di Puskesmas Getasan tersebut juga disebabkan karena faktor kebijakan Pemerintah Kabupaten Semarang sendiri yang sejak tahun 2008 menggratiskan tarif bagi masyarakat yang berobat di puskemas. Melalui kebijakan tersebut akhirnya banyak masyarakat, khususnya masyarakat yang 
kurang mampu untuk menjadikan Puskesmas Getasan sebagai tempat rujukan utama kesehatan mereka. Sedangkan Sumber Daya Manusia (SDM) Puskesmas relatif terbatas, sehingga kebutuhan pelayanan untuk setiap pegawai Puskesmas terhadap masyarakat yang memanfaatkan jasa pelayanan Puskesmas sangatlah tinggi. Hal inilah yang terkadang menjadi pemicu kurang maksimalnya pegawai dalam memberikan pelayanan kesehatan yang berkualitas terhadap masyarakat. Namun demikian untuk mengetahui kebenarannya perlu dilakukan penelitian secara lebih mendalam.

Penelitian tentang pengaruh kondisi psikis, kompensasi, dan lingkungan kerja terkait dengan masalah kualitas pelayanan di Puskemas Getasan selama ini belum pernah dilakukan. Hal inilah yang mendorong peneliti untuk melakukan penelitian tentang hal tersebut. Sebab menurut hasil pengamatan peneliti rendahnya kualitas pelayanan yang diberikan oleh pegawai di puskesmas tersebut diduga karena dipicu oleh ketiga faktor tersebut. Hasil observasi yang dilakukan peneliti terhadap 10 orang pegawai puskesmas pada tanggal 14 Januari 2019 menunjukkan, bahwa menurut 8 orang pegawai $(80 \%)$ yang menjadi responden, beban yang tinggi yang diterima pegawai karena banyaknya pasien yang harus dilayani menjadikan beban psikis bagi mereka, seperti turunnya motivasi kerja, sehingga terkadang sikap pegawai kurang simpatik terhadap masyarakat yang mereka layani.

Contoh lain yang berkaitan dengan kompensasi, menurut 10 orang (100\%) pegawai yang menjadi responden terdapat perbedaan yang jauh kompensasi yang diterima antar pegawai karena hanya perbedaan golongan, walaupun terkadang pegawai dengan golongan rendah telah bekerja maksimal, tetap saja kompensasi yang mereka terima lebih rendah dari pegawai dengan golongan lebih tinggi, walaupun mereka tidak bekerja sekeras pegawai golongan rendah. Hal tersebut dapat dilihat dari penangan kasus BPJS, misal: pasien BPJS dengan golongan rendah mendapat kompensasi sebesar Rp. 5000,- x 14.000 pasien yang ditangani, sementara pegawai dengan golongan lebih tinggi mendapat kompensasi Rp. 10.000,- x 14.000. Model pembagian kompensasi tersebut tentunya menjadikan keluhan bagi pegawai dengan golongan rendah, dan efeknya kualitas pelayanan yang diberikan menjadi kurang bermutu.

Berikutnya masalah lingkungan kerja, menurut 9 orang (90\%) pegawai yang menjadi responden, pegawai bagian administrasi sering memberikan bantuan kepada 
bagian pelayanan kesehatan dalam menangani pasien, namun pada saat bagian administrasi kewalahan menyelesaikan pekerjaan pegawai bagian pelayanan kesehatan sering tidak bersedia memberikan bantuan. Hal tersebut terkadang juga menjadi keluhan bagi pegawai administrasi. Masalah lain, kendaraan ambulan yang jumlahnya hanya 1 (satu), hal tersebut terkadang menjadikan proses pelayanan kesehatan menjadi sedikit terhambat.

Berdasarkan latar belakang permasalahan tersebut di atas, maka judul yang diajukan dalam penelitian ini adalah "Pengaruh Kondisi Psikis Pegawai, Kompensasi, dan Lingkungan Kerja Terhadap Kualitas Pelayanan Pegawai UPTD Puskesmas Getasan Kabupaten Semarang”.

\section{Rumusan Masalah}

Berdasarkan latar belakang masalah tersebut di atas, maka masalah dalam penelitian ini dapat dirumuskan sebagai berikut:

1. Apakah kondisi psikis pegawai Puskesmas berpengaruh terhadap kualitas pelayanan Pegawai UPTD Puskesmas Getasan Kabupaten Semarang?

2. Apakah kompensasi berpengaruh terhadap kualitas pelayanan Pegawai UPTD Puskesmas Getasan Kabupaten Semarang?

3. Apakah lingkungan kerja berpengaruh terhadap kualitas pelayanan Pegawai UPTD Puskesmas Getasan Kabupaten Semarang?

4. Apakah kondisi psikis pegawai, kompensasi, dan lingkungan kerja secara simultan berpengaruh terhadap kualitas pelayanan Pegawai UPTD Puskesmas Getasan Kabupaten Semarang?

\section{Tujuan dan Manfaat Penelitian}

Berpijak dari rumusan masalah penelitian tersebut di atas maka tujuan yang hendak dicapai dalam penelitian ini adalah:

1. Untuk mengetahui pengaruh kondisi psikis pegawai terhadap kualitas pelayanan Pegawai UPTD Puskesmas Getasan Kabupaten Semarang.

2. Untuk mengetahui pengaruh kompensasi terhadap kualitas pelayanan Pegawai UPTD Puskesmas Getasan Kabupaten Semarang.

3. Untuk mengetahui pengaruh lingkungan kerja terhadap kualitas pelayanan Pegawai UPTD Puskesmas Getasan Kabupaten Semarang. 
4. Untuk mengetahui pengaruh kondisi psikis pegawai, kompensasi, dan lingkungan kerja secara simultan terhadap kualitas pelayanan Pegawai UPTD Puskesmas Getasan Kabupaten Semarang.

Secara teoritis, penelitian ini diharapkan dapat bermanfaat sebagai bahan untuk menjelaskan pengaruh kondisi psikis pegawai, kompensasi, dan lingkungan kerja terhadap kualitas pelayanan Pegawai UPTD Puskesmas Getasan Kabupaten Semarang. Selain itu hasil penelitian ini dapat dijadikan masukan terutama sebagai pertimbangan dalam penyusunan kebijakan-kebijakan oleh pihak Kepala UPTD Puskesmas Getasan Kabupaten Semarang.

\section{PAPARAN TEORITIS}

\section{Kondisi Psikis}

Kondisi psikis atau faktor psikologis adalah faktor yang berhubungan dengan kejiwaan karyawan. Kondisi psikis menyangkut hal yang bersifat sangat personal dan melekat pada individu seseorang (As'ad, 2006 : 115). Luthans, et al (2007:325) menjelaskan lebih jauh bahwa kondisi psikis karyawan merupakan modal yang dimiliki karyawan untuk dapat meningkatkan nilai-nilai potensial karyawan dalam berbagai hal, seperti dalam mengambil sudut pandang yang berbeda, mengambil kesempatan, mampu beradaptasi atau menyesuaikan diri dan mampu meningkatkan well-being. Seseorang dengan modal psikologi yang tinggi (lebih baik) akan lebih fleksibel dan mudah beradaptasi untuk melakukan beberapa hal dalam memenuhi tuntutan pekerjaan. Dimana di saat yang bersamaan modal psikologi yang dimiliki akan membantu mengembangkan dan meningkatkan kemampuan serta well-being yang dimiliki. As'ad (2006 : 115) menjelaskan bahwa kondisi psikis dapat dinilai dari beberapa faktor, yaitu: Intelegensi, Bakat, Minat, Kepribadian, Motivasi, Edukasi.

\section{Kompensasi}

Salah satu fungsi tradisional manajemen sumber daya manusia adalah penentuan kompensasi para karyawannya. Dalam organisasi modern, dengan beraneka rupa program tunjangan karyawan yang mahal, program insentif gaji dan skala gaji yang terstruktur, tugas kompensasi bahkan lebih sulit dan menantang bagi spesialis sumber daya manusia.

Panggabean (2002:75) menyatakan bahwa kompensasi acapkali juga disebut sebagai penghargaan dan dapat didefinisikan sebagai setiap bentuk penghargaan yang 
diberikan kepada karyawan sebagai balas jasa atas kontribusi yang mereka berikan kepada organisasi. Sedang menurut menurut Simamora (2006:540), kompensasi didefinisikan sebagai apa yang diterima oleh karyawan sebagai ganti kontribusi mereka kepada organisasi. Sementara menurut Sitohang (2007:220), kompensasi adalah pengaturan pemberian balas jasa bagi karyawan dan para pimpinan atau manajer baik berupa finansial maupun barang dan jasa pelayanan yang diterima oleh setiap orang karyawan.

Berdasarkan definisi-definisi tersebut di atas, maka kompensasi secara singkat merupakan bentuk imbalan jasa yang diberikan oleh perusahaan baik dalam bentuk finansial maupun non finansial sebagai bentuk kontribusi karyawan/pegawai pada perusahaan/organisasi tempat mereka bekerja. Sitohang (2007:220) menjelaskan, bahwa komponen-komponen kompensasi meliputi: Gaji, Insentif, Tunjangan, dan Fasilitas-fasilitas lainnya. Fasilitas-fasilitas lain disini dapat berupa program asuransi, program pensiun, ataupun bayaran saat tidak masik kerja. Simamora (2006:540) menjelaskan, bahwa pada saat dikelola secara benar, kompensasi membantu organisasi mencapai tujuan-tujuannya serta memperoleh, memelihara dan mempertahankan tenaga kerja yang produktif. Begitu pentingnya faktor kompensasi dalam mendorong kinerja karyawan, maka sudah sewajarnya jika pihak perusahaan/organisasi menciptakan sistem sedemikian rupa agar kompensasi yang diberikan kepada karyawan/pegawainya memenuhi berbagai persyaratan, yaitu: 1) Kompensasi harus dapat memenuhi kebutuhan minimal, 2) Kompensasi harus dapat meningkat, 3) Kompensasi harus dapat menimbulkan semangat dan kegairahan kerja, 4) Kompensasi harus adil, 5) Kompensasi tidak boleh bersifat statis, 6) Komposisi dari kompensasi yang diberikan.

\section{Lingkungan Kerja}

Menurut Nitisemito (2002:183) lingkungan kerja segala sesuatu yang ada disekitar para pekerja yang dapat mempengaruhi dirinya dalam menjalankan tugastugas yang diembankan. Sedang menurut Moekijat (2009:135), lingkungan kerja adalah sesuatu yang berada disekitar para pekerja yang meliputi cahaya, warna, udara, suara serta musik yang mempengaruhi dirinya dalam menjalankan tugas-tugas yang diberikan. Sementara menurut Sedarmayati (2009:1) lingkungan kerja adalah keseluruhan alat perkakas dan bahan yang dihadapi, lingkungan sekitarnya di mana 
seseorang bekerja, metode kerjanya, serta pengaturan kerjanya baik sebagai perseorangan maupun sebagai kelompok.

Dari beberapa pendapat di atas, disimpulkan bahwa lingkungan kerja merupakan segala sesuatu yang ada di sekitar karyawan/pegawai pada saat bekerja, baik yang berbentuk fisik ataupun non fisik, langsung atau tidak langsung, yang dapat mempengaruhi dirinya dan pekerjaanya saat bekerja.

Sedarmayanti (2009:21) menyatakan bahwa secara garis besar, jenis lingkungan kerja terbagi menjadi 2 (dua) yakni : (a) lingkungan kerja fisik, dan (b) lingkungan kerja non fisik. Lingkungan kerja fisik adalah semua keadaan berbentuk fisik yang terdapat di sekitar tempat kerja yang dapat mempengaruhi karyawan baik secara langsung maupun scara tidak langsung. Untuk dapat memperkecil pengaruh lingkungan fisik terhadap karyawan, maka langkah pertama adalah harus mempelajari manusia, baik mengenai fisik dan tingkah lakunya maupun mengenai fisiknya, kemudian digunakan sebagai dasar memikirkan lingkungan fisik yang sesuai. Berikut ini beberapa faktor yang diuraikan Sedarmayanti (2009:21) yang dapat mempengaruhi terbentuknya suatu kondisi lingkungan kerja dikaitkan dengan kemampuan karyawan, diantaranya adalah : Penerangan di Tempat Kerja, Sirkulasi Udara di Tempat Kerja, Bau-bauan di Tempat Kerja, Keamanan di Tempat Kerja.

Menurut Sadarmayanti (2009:31) lingkungan kerja non fisik adalah semua keadaan yang terjadi yang berkaitan dengan hubungan kerja, baik hubungan dengan atasan maupun hubungan sesama rekan kerja, ataupun hubungan dengan bawahan. Lingkungan non fisik ini merupakan kelompok lingkungan kerja yang tidak bisa diabaikan. Perusahaan hendaknya dapat mencerminkan kondisi yang mendukung kerja sama antara tingkat atasan, bawahan maupun yang memiliki status jabatan yang sama di perusahaan. Ditambahkan oleh Nitisemito (2002:171), yang termasuk dalam hal ini adalah suasana kekeluargaan, komunikasi yang baik, dan pengendalian diri.

\section{Kualitas Pelayanan}

Kualitas jasa jauh lebih sukar didefinisikan, dijabarkan, dan diukur bila dibandingkan dengan kualitas barang. Bila ukuran kualitas dan pengendalian kualitas telah lama di kembangkan dan diterapkan untuk barang-barang berwujud (tangible goods), maka untuk jasa berbagai upaya justru sedang di kembangkan untuk merumuskan ukuran-ukuran semacam itu, namun demikian pada prinsipnya, definisi 
kualitas jasa berfokus pada upaya pemenuhan kebutuhan dan keinginan pelanggan, serta ketepatan penyampaiannya untuk mengimbangi harapan pelanggan (Tjiptono, $2006: 259)$.

Menurut Tjiptono (2006:260), kualitas pelayanan merupakan tingkat keunggulan (excellence) yang diharapkan dan pengendalian atas keunggulan tersebut untuk memenuhi keinginan pelanggan. Sedang menurut Zeithaml, et al dalam Lupiyoadi (2009:148), kualitas pelayanan adalah seberapa jauh perbedaan antara kenyataan dan harapan pelanggan atas layanan yang mereka terima atau peroleh. Berdasarkan definisi tersebut, maka secara singkat kualitas pelayanan dapat didefinisikan gab antara pelayanan yang diterima, dan yang diharapkan oleh pelanggan.

Sementara untuk perusahaan jasa dapat dilakukan dengan menggunakan dimensi kualitas pelayanan yang dikembangkan oleh Zeithaml, et al dalam Lupiyoadi (2009:148). Dalam penelitiannya Zeithaml, et al menemukan 5 (lima) dimensi yang dapat digunakan sebagai indikator kualitas pelayanan perusahaan jasa, yaitu: 1) Bukti langsung (tangibles). Bukti langsung (tangibles) adalah kemampuan dalam menunjukkan eksistensinya kepada pihak eksternal, yang meliputi: kebersihan dan kenyamanan ruangan, penampilan petugas, dan kelengkapan fasilitas fisik dalam menunjang pelayanan. Indikator bukti langsung (tangibles) meliputi: kebersihan dan kenyamanan ruangan, penampilan petugas, dan kelengkapan fasilitas fisik dalam menunjang pelayanan, 2) Kehandalan (reliability). Kehandalan (reliability) adalah kemampuan untuk melaksanakan jasa yang dijanjikan dengan tepat dan terpercaya, yang meliputi: jadwal pelayanan dijalankan secara tepat, prosedur pelayanan yang tidak berbelit-belit, dan ketepatan dalam memberikan pelayanan. Indikator kehandalan (reliability) meliputi: jadwal pelayanan yang dijalankan secara tepat, prosedur pelayanan yang tidak berbelit-belit, sikap yang simpatik, pelayanan dengan akurasi yang tinggi, 3) Daya tanggap (responsiveness). Daya tanggap (responsiveness) didefinisikan sebagai kemauan untuk membantu dan memberikan pelayanan yang cepat dan tepat kepada pelanggan, dengan penyampaian informasi yang jelas. Untuk itu indikator untuk mengukur daya tanggap (responsiveness) meliputi: kesediaan petugas untuk segera memberikan bantuan kepada konsumen yang mengalami kesulitan, kesediaan petugas untuk memberikan pelayanan dengan cepat, kesediaan 
petugas untuk memberikan pelayanan dengan tepat, kesediaan petugas untuk memberikan informasi dengan jelas, 4) Jaminan (assurance). Jaminan (assurance) adalah pengetahuan, kesopanan, dan kemampuan para pegawai untuk menumbuhkan rasa percaya pelanggan. Indikator untuk jaminan (assurance) meliputi: pengetahuan dan kapasitas petugas yang memadai, pelayanan petugas yang sopan dan ramah, kemampuan petugas dalam menanamkan kepercayaan, keamanan selama bertransaksi, 5) Empati (empathy). Empati (empathy) adalah memberikan perhatian yang tulus dan bersifat individual atau pribadi yang diberikan kepada pelanggan dengan berupaya memahami keinginan pelanggan. Indikator untuk empati (empathy), yaitu: petugas memberikan pelayanan tanpa memandang status sosial, petugas memberi perhatian yang bersifat pribadi, kepedulian petugas pada konsumen, petugas memberi perhatian khusus kepada konsumen.

\section{Kerangka Pemikiran}

Sebagai organisasi publik yang bertanggung jawab dalam memenuhi kebutuhan kesehatan masyarakat, tentunya pihak puskesmas dituntut untuk mampu menampilkan kualitas pelayanan yang bermutu sebagai sebuah bentuk pencapaian atas kinerjanya. Kondisi tersebut dapat diciptakan apabila pihak manajemen puskesmas sendiri mampu menjaga kondisi psikis (psikologis) pegawainya, memberikan kompensasi yang layak kepada pegawainya, dan mampu menciptakan lingkungan kerja yang baik.

Berdasarkan penjelasan tersebut maka model kerangka pemikiran dalam penelitian ini adalah sebagai berikut:

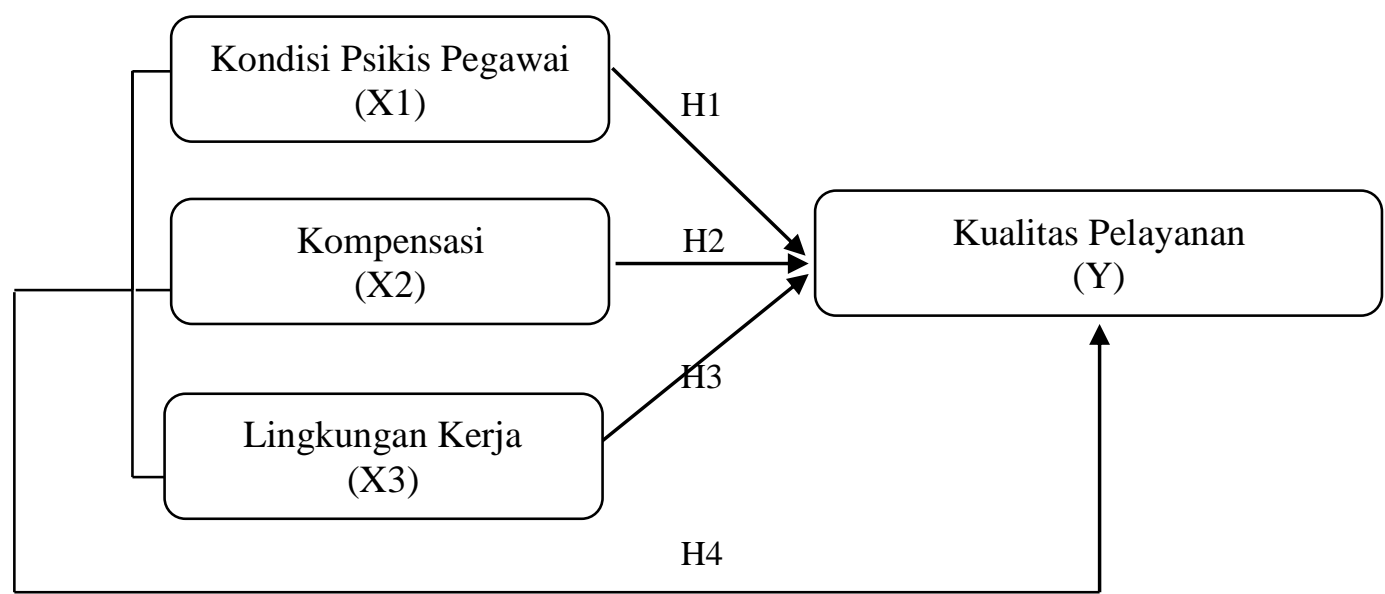

Gambar 1.

Pengaruh Kondisi Psikis Pegawai, Kompensasi, Dan Lingkungan Kerja 
Keterangan :

\section{Model Kerangka Pemikiran}

$\begin{aligned} \text { Variabel independent }(\mathrm{X}) \quad= & \text { Kondisi Psikis (X1) } \\ & \text { Kompensasi (X2) } \\ & \text { Lingkungan Kerja (X3) } \\ \text { Variabel Dependen (Y) }= & \text { Kualitas Pelayanan (Y) }\end{aligned}$

\section{Hipotesis Penelitian}

Hipotesis adalah proporsi yang masih bersifat sementara dan masih harus diuji kebenarannya (Hasan, 2004 : 13). Adapun hipotesis yang diajukan dalam penelitian ini adalah :

1. Ada pengaruh signifikan kondisi psikis pegawai terhadap kualitas pelayanan Pegawai UPTD Puskesmas Getasan Kabupaten Semarang.

2. Ada pengaruh signifikan kompensasi terhadap kualitas pelayanan Pegawai UPTD Puskesmas Getasan Kabupaten Semarang.

3. Ada pengaruh signifikan lingkungan kerja terhadap kualitas pelayanan Pegawai UPTD Puskesmas Getasan Kabupaten Semarang.

4. Ada pengaruh signifikan kondisi psikis pegawai, kompensasi, dan lingkungan kerja secara simultan terhadap kualitas pelayanan Pegawai UPTD Puskesmas Getasan Kabupaten Semarang.

\section{METODE PENELITIAN}

\section{Populasi dan Sampel}

Populasi adalah keseluruhan unit atau individu dalam ruang lingkup yang ingin diteliti (Supramono dan Sugiarto, 2003:2). Dalam penelitian ini populasi yang dimaksud adalah seluruh pegawai UPTD Puskesmas Getasan Kabupaten Semarang yang berjumlah 50 orang. Sampel adalah sebagian dari populasi yang ingin diteliti, yang ciri-ciri dan keberadaannya diharapkan mampu mewakili atau menggambarkan ciri-ciri dan keberadaan populasi yang sebenarnya (Supramono dan Sugiarto, 2003 : 13). Jumlah sampel dalam penelitian ini adalah sebanyak 50, sehingga dalam penelitian ini jumlah populasi secara keseluruhan diambil sebagai sampel. Untuk itu teknik yang digunakan dalam penentuan jumlah sampel penelitian ini adalah sapling jenuh/sensus, yaitu cara pengambilan sampel dengan mengambil semua anggota populasi menjadi sampel (Hidayat, 2010:83). 


\section{Definisi Konsep dan Definisi Operasional}

Berikut definisi konsep dan operasionalisasi dari masing-masing konsep yang dipilih dalam penelitian ini, yaitu:

\section{a. Kondisi Psikis}

Kondisi psikis atau faktor psikologis adalah faktor yang berhubungan dengan kejiwaan karyawan. Kondisi psikis menyangkut hal yang bersifat sangat personal dan melekat pada individu seseorang (As'ad, 2006 : 115). Kondisi psikis meliputi diukur dengan indikator sebagai berikut: Intelegensia, Bakat, Minat, Kepribadian, Motivasi (As'ad, 2006 : 115).

\section{b. Kompensasi}

Kompensasi adalah pengaturan pemberian balas jasa bagi karyawan dan para pimpinan atau manajer baik berupa finansial maupun barang dan jasa pelayanan yang diterima oleh setiap orang karyawan (Sitohang, 2007:220). Kompensasi diukur dengan indikator sebagai berikut: Gaji, Insentif, Tunjangan, Fasilitasfasilitas lain (Sitohang, $2007: 222$ ).

\section{c. Lingkungan Kerja}

Lingkungan kerja adalah keseluruhan alat perkakas dan bahan yang dihadapi, lingkungan sekitarnya di mana seseorang bekerja, metode kerjanya, serta pengaturan kerjanya baik sebagai perseorangan maupun sebagai kelompok (Sedarmayati, 2009:1). Lingkungan kerja diukur dengan indikator-indikator sebagai berikut: Penerangan di tempat kerja, Sirkulasi udara di tempat kerja, Bau-bauan di tempat kerja, Keamanan di tempat kerja, Suasana kekeluargaan, Komunikasi yang baik, Pengendalian diri (Sedarmayati, 2009:21).

\section{d. Kulitas Pelayanan}

Kualitas pelayanan adalah seberapa jauh perbedaan antara kenyataan dan harapan pelanggan atas layanan yang mereka terima atau peroleh (Zeithaml, et al dalam Lupiyoadi, 2009:148). Kualitas pelayanan diukur berdasarkan indicator-indikator sebagai berikut: Tangible (Bukti fisik), Reliability (Keandalan), Responsiveness (Daya tanggap), Assurance (Jaminan), Empathy (Empati) (Zeithaml, et al dalam Lupiyoadi, 2009:148). 


\section{ANALISIS DATA}

Dalam penelitian ini data dikumpulkan melalui kuesioner. Menurut Sugiyono (2010:142) kuesioner merupakan teknik pengumpulan data yang dilakukan dengan cara memberi seperangkat pertanyaan atau pernyataan tertulis kepada responden untuk dijawabnya. Kuesioner dalam hal ini terdiri dari 4 (empat) hal, yaitu: kondisi psikis pegawai, kompensasi, lingkungan kerja, dan kualitas pelayanan. Skala yang digunakan untuk mengukur kuesioner dalam penelitian ini adalah skala Likert 4 (empat) tingkat, yaitu Sangat Tidak Setuju (STS) skor 1, Tidak Setuju (TS) skor 2, Setuju (S) skor 3, dan Sangat Setuju (SS) skor 4. Alat analisis yang digunakan dalam penelitian ini meliputi uji validitas dan reliabilitas serta uji regresi linier berganda. Uji validitas digunakan untuk mengukur sah atau valid tidaknya suatu kuesioner (Ghozali, 2004 : 45).

Analisis regresi ini digunakan untuk menjawab hipotesis penelitian. Secara matematis persamaan regresi linier berganda dalam penelitian ini dapat dijabarkan sebagai berikut :

$\mathrm{Y}=\mathrm{a}+\mathrm{b}_{1} \mathrm{X}_{1}+\mathrm{b}_{2} \mathrm{X}_{2}+\mathrm{b}_{3} \mathrm{X}_{3}$ (Sugiyono, $2002: 250)$

Keterangan :

$\mathrm{Y}=$ Kualitas Pelayanan (Variabel dependen)

$\mathrm{X}_{1}=$ Variabel Kondisi Psikis

$\mathrm{X}_{2}=$ Variabel Kompensasi

$\mathrm{X}_{3}=$ Variabel Lingkungan Kerja

$b_{1}=$ Koefisien regresi Variabel Kondisi Psikis

$\mathrm{b}_{2}=$ Koefisien regresi Variabel Kompensasi

$\mathrm{b}_{3}=$ Koefisien regresi Variabel Lingkungan Kerja

a $=$ Konstanta

\section{HASIL DAN PEMBAHASAN}

\section{Uji Regresi Linier Berganda}

Dari hasil analisa regresi dijelaskan mengenai persamaan regresi linier berganda dan arti dari masing-masing nilai koefisien regresi sebagai berikut: 
Tabel 1

Hasil Analisis Regresi

\begin{tabular}{|c|c|c|c|c|c|c|}
\hline \multicolumn{7}{|c|}{ Coefficients $^{a}$} \\
\hline \multirow{2}{*}{\multicolumn{2}{|c|}{ Model }} & \multicolumn{2}{|c|}{$\begin{array}{l}\text { Unstandardiz ed } \\
\text { Coefficients }\end{array}$} & \multirow{2}{*}{$\begin{array}{c}\text { Standardized } \\
\text { Coefficients } \\
\text { Beta } \\
\end{array}$} & \multirow[b]{2}{*}{$\mathrm{t}$} & \multirow[b]{2}{*}{ Sig. } \\
\hline & & $\mathrm{B}$ & Std. Error & & & \\
\hline \multirow[t]{4}{*}{1} & (Constant) & 3,262 & 1,460 & & 2,233 &, 030 \\
\hline & Kondisi Psikis (X1) & ,191 &, 073 & ,237 & 2,611 & ,012 \\
\hline & Kompensasi (X2) & 159 &, 060 & 222 & 2,638 &, 011 \\
\hline & Lingkungan Kerja (X3) &, 538 & ,085 &, 596 & 6,311 &, 000 \\
\hline
\end{tabular}

a. Dependent Variable: Kualitas Pelayanan (Y)

Berdasarkan tabel 1 di atas dapat dijelaskan persamaan regresi linier berganda sebagai berikut : $\mathrm{Y}=3,262+0,191 \mathrm{X}_{1}+0,159 \mathrm{X}_{2}+0,538 \mathrm{X}_{3}$. Nilai-nilai dalam persamaan tersebut dapat dijelaskan hal-hal sebagai berikut :

1) Nilai konstan $\left(b_{o}\right)=3,262$ dan bertanda positif, artinya apabila variabel kondisi psikis $\left(\mathrm{X}_{1}\right)$, kompensasi $\left(\mathrm{X}_{2}\right)$, dan lingkungan kerja $\left(\mathrm{X}_{3}\right)$ dianggap konstan, maka besarnya nilai variabel kualitas pelayanan $(Y)=3,262$ satuan.

2) Koefisien regresi variabel kondisi psikis $\left(b_{1}\right)=0,191$ dan bertanda positif, artinya setiap perbaikan kondisi psikis pegawai sebesar satu-satuan akan meningkatkan kualitas pelayanan Pegawai UPTD Puskesmas Getasan Kabupaten Semarang sebesar 0,191 satuan dengan asumsi variabel lainnya dianggap tetap.

3) Koefisien regresi variabel kompensasi $\left(b_{2}\right)=0,159$ dan bertanda positif, artinya setiap dilakukan peningkatan kompensasi yang diberikan kepada pegawai sebesar satu-satuan akan meningkatkan kualitas pelayanan Pegawai UPTD Puskesmas Getasan Kabupaten Semarang sebesar 0,159 satuan dengan asumsi variabel lainnya dianggap tetap.

4) Koefisien regresi variabel lingkungan kerja $\left(b_{3}\right)=0,538$ dan bertanda positif, artinya setiap dilakukan peningkatan lingkungan kerja pegawai sebesar satusatuan akan meningkatkan kualitas pelayanan Pegawai UPTD Puskesmas Getasan Kabupaten Semarang sebesar 0,538 satuan dengan asumsi variabel lainnya dianggap tetap. 


\section{Pengujian Hipotesis}

\section{Pengaruh Kondisi Psikis Terhadap Kualitas Pelayanan}

Hasil analisis pengaruh kondisi psikis terhadap kualitas pelayanan Pegawai UPTD Puskesmas Getasan Kabupaten Semarang diperoleh nilai t-hitung 2,611 dan nilai koefisien regresi sebesar 0,191 satuan. Sedangkan nilai t-tabel untuk degree of freedom 46 (n-k-1 = 50-3-1), level of significance $(\alpha)$ 0,025 adalah 2,013. Berdasarkan nilai-nilai t tersebut, maka dapat disimpulkan bahwa nilai t-hitung $(2,611)>$ nilai t-tabel $(2,013)$, maka terdapat pengaruh kondisi psikis terhadap kualitas pelayanan, sehingga pernyataan hipotesis I penelitian, "Ada pengaruh signifikan kondisi psikis pegawai terhadap kualitas pelayanan Pegawai UPTD Puskesmas Getasan Kabupaten Semarang”, diterima.

Penerimaan hipotesis penelitian ini menunjukkan bahwa setiap dilakukan perbaikan kondisi psikis pegawai, baik dari aspek intelegensia, bakat, minat, kepribadian, dan motivasi akan meningkatkan kualitas pelayanan yang dilakukan pegawai, baik dari aspek tangible (bukti fisik), reliability (keandalan), responsiveness (daya tanggap), assurance (jaminan), dan empathy (empati).

\section{Pengaruh Kompensasi Terhadap Kualitas pelayanan}

Hasil analisis pengaruh kompensasi terhadap kualitas pelayanan Pegawai UPTD Puskesmas Getasan Kabupaten Semarang diperoleh nilai t-hitung 2,638 dan nilai koefisien regresi $\left(b_{2}\right)$ sebesar 0,159 satuan. Sedangkan nilai t-tabel untuk degree of freedom 46 (n-k-1 = 50-3-1), level of significance $(\alpha) 0,025$ adalah 2,013.

Perbandingan kedua nilai $\mathrm{t}$ di atas menunjukkan jika nilai t-hitung $(2,638)>$ nilai t-tabel $(2,013)$, maka terdapat pengaruh kompensasi terhadap kualitas pelayanan Puskesmas Getasan, sehingga pernyataan hipotesis II penelitian, "Ada pengaruh signifikan kompensasi terhadap kualitas pelayanan Pegawai UPTD Puskesmas Getasan Kabupaten Semarang", diterima. Penerimaan hipotesis penelitian II tersebut membuktikan bahwa setiap dilakukan peningkatan kompensasi, baik dari aspek gaji, insentif, tunjangan, dan fasilitas-fasilitas lain, akan meningkatkan kualitas pelayanan yang dilakukan pegawai, baik dari aspek 
tangible (bukti fisik), reliability (keandalan), responsiveness (daya tanggap), assurance (jaminan), dan empathy (empati).

\section{Pengaruh Lingkungan Kerja Terhadap Kualitas Pelayanan}

Hasil analisis pengaruh lingkungan kerja terhadap kualitas pelayanan Puskesmas Getasan diperoleh nilai t-hitung 6,311, dan nilai koefisien regresi $\left(b_{3}\right)$ sebesar 0,538 satuan. Sedangkan nilai t-tabel untuk degree of freedom 46 (n-k-1 = 50-3-1), level of significance ( $\alpha$ ) 0,025 adalah sebesar 2,013. Perbandingan kedua nilai $\mathrm{t}$ di atas menunjukkan jika nilai t-hitung $(6,311)>$ nilai t-tabel $(2,013)$, maka terdapat pengaruh lingkungan kerja terhadap kualitas pelayanan, sehingga pernyataan hipotesis III penelitian, "Ada pengaruh signifikan lingkungan kerja terhadap kualitas pelayanan Pegawai UPTD Puskesmas Getasan Kabupaten Semarang", diterima. Penerimaan hipotesis penelitian III tersebut membuktikan bahwa setiap dilakukan perbaikan lingkungan kerja, baik dari aspek penerangan di tempat kerja, sirkulasi udara di tempat kerja, bau-bauan di tempat kerja, keamanan di tempat kerja, suasana kekeluargaan, komunikasi yang baik, dan pengendalian diri, akan meningkatkan kualitas pelayanan yang dilakukan pegawai, baik dari aspek tangible (bukti fisik), reliability (keandalan), responsiveness (daya tanggap), assurance (jaminan), dan empathy (empati).

\section{Pengaruh Kondisi Psikis, Kompensasi, dan Lingkungan Kerja, Secara Simultan Terhadap Kualitas Pelayanan}

Pengujian pengaruh variabel Kondisi Psikis $\left(\mathrm{X}_{1}\right)$, Kompensasi $\left(\mathrm{X}_{2}\right)$, dan Lingkungan kerja $\left(\mathrm{X}_{3}\right)$ secara simultan terhadap kualitas pelayanan $(\mathrm{Y})$ diperoleh nilai F-hitung sebagai berikut:

Tabel 2

Hasil Uji F

ANOVA

\begin{tabular}{|c|c|c|c|c|c|c|}
\hline Model & & $\begin{array}{l}\text { Sum of } \\
\text { Squares }\end{array}$ & df & Mean Square & $\mathrm{F}$ & Sig. \\
\hline \multirow[t]{3}{*}{1} & Regression & 80,223 & 3 & 26,741 & 38,110 &, $000^{\mathrm{a}}$ \\
\hline & Residual & 32,277 & 46 & ,702 & & \\
\hline & Total & 112,500 & 49 & & & \\
\hline
\end{tabular}

a. Predictors: (Constant), Lingkungan Kerja (X3), Kompens asi (X2), Kondisi Psikis (X1)

b. Dependent Variable: Kualitas Pelayanan (Y) 
Tabel 2 menjelaskan bahwa besarnya nilai F-hitung adalah 38,110 sedangkan nilai F-tabel pada $\mathrm{df}_{1}=3, \mathrm{df}_{2}=46$, dan level of significance $(\alpha) 5 \%$ sebesar 2,61. Dengan membandingkan kedua nilai $\mathrm{F}$ tersebut, disimpulkan nilai F-hitung $(38,110)>$ F-tabel $(2,81)$, maka secara simultan kondisi psikis, kompensasi, dan lingkungan kerja berpengaruh terhadap kualitas pelayanan, sehingga pernyataan hipotesis IV, “Ada pengaruh signifikan kondisi psikis pegawai, kompensasi yang diterima pegawai, dan lingkungan kerja pegawai secara simultan terhadap kualitas pelayanan Pegawai UPTD Puskesmas Getasan Kabupaten Semarang”, diterima. Diterimanya hipotesis IV penelitian di atas menunjukkan bahwa variabel-variabel independen dalam hal ini, yaitu Kondisi Psikis $\left(\mathrm{X}_{1}\right)$, Kompensasi $\left(\mathrm{X}_{2}\right)$, dan Lingkungan kerja $\left(\mathrm{X}_{3}\right)$, layak dijadikan sebagai prediktor bagi variabel dependen, dalam hal ini variabel Kualitas Pelayanan (Y).

\section{Koefisien Determinasi (Adjusted R Square)}

Koefisien determinasi adalah suatu indikator yang menunjukkan besarnya varians variabel dependen yang bisa dijelaskan oleh variabel independen. Dalam hal ini koefisien determinasi digunakan untuk mengetahui besarnya varians variabel Kualitas Pelayanan (Y) yang dapat dijelaskan oleh variabel independen (Kondisi Psikis $\left(\mathrm{X}_{1}\right)$, Kompensasi $\left(\mathrm{X}_{2}\right)$, dan Lingkungan Kerja $\left(\mathrm{X}_{3}\right)$.

Hasil analisis regresi linier berganda diperoleh nilai koefisien determinasi atau Adjusted $R$ Square sebagai berikut:

\section{Tabel 3}

\section{Hasil Koefisien Determinasi}

Model Summary

\begin{tabular}{|l|r|r|r|r|}
\hline Model & $\mathrm{R}$ & $\mathrm{R}$ Square & $\begin{array}{c}\text { Adjusted } \\
\mathrm{R} \text { Square }\end{array}$ & $\begin{array}{c}\text { Std. Error of } \\
\text { the Estimate }\end{array}$ \\
\hline 1 &, $844^{\mathrm{a}}$ &, 713 &, 694 &, 83766 \\
\hline
\end{tabular}

a. Predictors: (Constant), Lingkungan Kerja (X3), Kompensasi (X2), Kondisi Psikis (X1)

Tabel 3 di atas menjelaskan bahwa nilai Adjusted $R$ Square hasil analisis data adalah sebesar 0,694, berarti 69,40\% variasi variabel dependen (Kualitas Pelayanan (Y)) dapat dijelaskan oleh variasi dari ketiga variabel independen, yaitu: Kondisi Psikis $\left(\mathrm{X}_{1}\right)$, Kompensasi $\left(\mathrm{X}_{2}\right)$, dan Lingkungan Kerja $\left(\mathrm{X}_{3}\right)$, sedangkan sisanya 30,60\% $(100 \%-69,40 \%)$ dijelaskan oleh variabel-variabel 
lain yang tidak diteliti, seperti: promosi jabatan, dukungan rekan kerja, beban kerja, stress kerja, dan lain sebagainya.

\section{KESIMPULAN}

Berdasarkan hasil analisis data dan pembahasan pada bab IV maka dapat peneliti simpulkan sebagai berikut :

1. Persamaan regresi dalam penelitian ini digambarkan sebagai berikut: $\mathrm{Y}=3,262+$ $0,191 X_{1}+0,159 X_{2}+0,538 X_{3}$. Nilai-nilai dalam persamaan tersebut menunjukkan, nilai konstan $\left(b_{o}\right)=3,262$, koefisien regresi variabel kondisi psikis $\left(b_{1}\right)=0,191$, koefisien regresi variabel kompensasi $\left(b_{2}\right)=0,159$, dan koefisien regresi variabel lingkungan kerja $\left(b_{3}\right)=0,538$. Berdasarkan nilai-nilai tersebut maka lingkungan kerja memiliki pengaruh yang paling dominan terhadap kualitas pelayanan Pegawai UPTD Puskesmas Getasan Kabupaten Semarang.

2. Hipotesis I penelitian "Ada pengaruh signifikan kondisi psikis pegawai terhadap kualitas pelayanan Pegawai UPTD Puskesmas Getasan Kabupaten Semarang", diterima, dibuktikan nilai t-hitung $(2,611)>$ nilai t-tabel $(2,013)$.

3. Hipotesis II penelitian, ”Ada pengaruh signifikan kompensasi terhadap kualitas pelayanan Pegawai UPTD Puskesmas Getasan Kabupaten Semarang”, diterima, dibuktikan nilai t-hitung $(2,638)>$ nilai t-tabel $(2,013)$.

4. Hipotesis III penelitian, "Ada pengaruh signifikan lingkungan kerja terhadap kualitas pelayanan Pegawai UPTD Puskesmas Getasan Kabupaten Semarang”, diterima, dibuktikan nilai t-hitung $(6,311)>$ nilai t-tabel $(2,013)$.

5. Hipotesis IV penelitian "Ada pengaruh signifikan kondisi psikis pegawai, kompensasi yang diterima pegawai, dan lingkungan kerja pegawai secara simultan terhadap kualitas pelayanan Pegawai UPTD Puskesmas Getasan Kabupaten Semarang", diterima, dibuktikan nilai F-hitung $(38,110)>$ F-tabel $(2,81)$.

6. Nilai Adjusted $R$ Square hasil analisis regresi adalah $69,40 \%$, artinya variasi variabel dependen (Kualitas Pelayanan (Y)) yang dapat dijelaskan oleh variasi dari ketiga variabel independen, yaitu: Kondisi Psikis $\left(\mathrm{X}_{1}\right)$, Kompensasi $\left(\mathrm{X}_{2}\right)$, dan Lingkungan Kerja $\left(\mathrm{X}_{3}\right)$ adalah sebesar 69,40\%, sedangkan sisanya 30,60\% (100\% $-69,40 \%$ ) dijelaskan oleh variabel-variabel lain yang tidak diteliti, seperti: promosi jabatan, dukungan rekan kerja, beban kerja, stress kerja, dan lain sebagainya.

\section{Saran}

Pengaruh Kondisi Psikis Pegawai, Kompensasi, Dan Lingkungan Kerja 
Berdasarkan hasil analisis data di atas peneliti dapat memberikan saran sebagai berikut:

1. Hasil penelitian menemukan bahwa lingkungan kerja merupakan variable yang paling dominan dalam mempengaruhi kualitas pelayanan, namun dalam penelitian ini juga ditemukan terdapat beberapa aspek lingkungan kerja yang perlu diperbaiki, terutama berkaitan dengan penerangan, kondisi sistem pertukaran udara, dan masalah kebersihan sampah. Memperbaiki kondisi tersebut pihak manajemen puskesmas perlu menambah watt lampu ruangan yang dinilai masih kurang terang, seperti halnya di ruang gudang penyimpanan obat, begitu juga dengan masalah pertukaran udara juga perlu ditambah jumlah ventilasi udara, baik berupa jendela ataupun loster. Kemudian untuk kebersihan, karena aktivitas pelayanan padat, maka ada baiknya perlu ditambah tenaga-tenaga honorer untuk bagian kebersihan, sehingga upaya menjaga kebersihan lebih optimal.

2. Berkenaan dengan kondisi psikis, hasil penelitian menemukan masalah yang berkaitan dengan pekerjaan dapat diselesaikan dengan baik, dan pekerjaan yang dihadapi sesuai dengan bakat. Mengatasi kondisi tersebut maka penting bagi pihak manajemen puskesmas melakukan evaluasi secara berkala terhadap kinerja para pegawainya, selain itu juga dapat ditempuh cara-cara seperti melakukan diklat pada pegawai-pegawai tertentu yang dinilai kurang. Pihak manajemen juga dapat melihat latar belakang pendidikan pegawai dalam menempatkan pegawai pada posisi tertentu.

3. Berkaitan dengan masalah kompensasi, hasil penelitian menemukan masalah keadilan kompensasi yang diberikan saat ini, kesesuaian kompensasi dengan beban kerja, kemampuan kompensasi dalam mendorong untuk lebih baik dalam bekerja, dan ketersediaan fasilitas dalam mendorong pegawai menampilkan layanan secara berkualitas, masih perlu diperbaiki. Melihat kondisi tersebut maka langkah yang dapat ditempuh pihak manajemen, yaitu dalam pemberian kompensasi bukan hanya memasukkan unsur jabatan pegawai di puskesmas menjadi satu-satunya pertimbangan, tapi masalah beban kerja pegawai juga perlu menjadi pertimbangan juga. Hal tersebut penting untuk memberikan rasa keadilan bagi setiap pegawai. 


\section{DAFTAR PUSTAKA}

As'ad, Moch. 2006. Seri Ilmu Sumber Daya manusia, Psikologi Industri. Liberty, Yogyakarta.

Depkes RI, 2004. Keputusan Menteri Kesehatan RI No. 128/Menkes/sk/II/2004 tentang Kebijakan Dasar Pusat Kesehatan Masyarakat. Jakarta: Depkes RI.

Ghozali, Imam, 2004. Analisis Multivariate Dengan Program SPSS. Badan Penerbit Universitas Diponegoro, Semarang.

Gomes, Faustino Cordoso, 2003. Manajemen Sumber Daya Manusia. Andi Offset, Yogyakarta.

Hartono, B, 2010. Promosi Kesehatan di Puskesmas dan Rumah Sakit. Rineka Cipta, Jakarta.

Hasan, Iqbal, 2004. Analisis Data Penelitian Dengan Statistik. Bumi Aksara, Jakarta.

Hasibuan, M. 2009. Organisasi dan Motivasi: Dasar Peningkatan Produktivitas. Bumi Aksara, Jakarta.

Hidayat, A. Aziz Alimul, 2010. Metode Penelitian Kebidanan. Salemba Medika, Jakarta.

Indriantoro, Nur dan Bambang Supomo, 2002. Metodologi Penelitian Bisnis: Untuk Akuntansi \& Manajemen. BPFE, Yogyakarta.

Khusnul, Khotimah, 2010. Hubungan Antara Persepsi Terhadap Lingkungan Kerja Psikologis Dengan Burnout Pada Perawat RSU Budi Rahayu Pekalongan. Skripsi Program SI Psikologi UNDIP, Semarang.

Lupiyoadi, Rambat, 2009. Manajemen Pemasaran Jasa. Salemba Empat, Jakarta.

Luthans, F., Avolio, B.J., Avey, J.B., Norman, S.M. 2007. Positive psychological capital: Measurement and relationship with performance and satisfaction. Personnel Psychology 2007, 60, 541-572.

Megawati, Sintara, 2010. Pengaruh Kompensasi Terhadap Produktivitas Kerja Karyawan PT. Panca Persada Mulia Magelang Melalui Motivasi Kerja Karyawan Sebagai Variabel Intervening. Skripsi Program SI Ekonomika dan Bisnis Universitas Kristen Satya Wacana, Salatiga.

Moekijat, 2009. Tata Laksana Kantor. Mandar Maju, Bandung.

Nitisemito, Alex S., 2002. Manajemen Personalia: Manajemen Sumber Daya Manusia. Ghalia Indonesia, Jakarta.

Notoatmodjo, Soekidjo, 2002. Metodologi Penelitian Kesehatan. Rineka Cipta, Jakarta.

Pandi, Afandi, 2009. Analisis Pengaruh Kondisi Psikis dan Kondisi Fisik Pegawai Terhadap Kualitas Pelayanan Puskesmas Jetak Getasan Kab Semarang. Jurnal STIE “AMA”, Salatiga, hal. 1-24.

Panggabean, Mutiara Sibarani, 2002. Manajemen Sumber Daya Manusia. Ghalia Indonesia, Jakarta. 
Putri, Suci Tresno, 2017. Pengaruh Kepuasan Kerja Terhadap Turnover Intention (Studi pada Hotel Delonix Karawang). SMART - Study \& Management Research, Vol XIV, No 3 - 2017, 42-51.

Santosa, Purbayu Budi dan Ashari, 2003. Statistika Teori dan Aplikasi dengan Program MS. Exel \& SPSS Versi 11. Universitas Diponegoro, Semarang.

Sedarmayanti, 2011. Manajemen Sumber Daya Manusia (Reformasi Birokrasi dan Manajemen Pegawai Negeri Sipil). Refika Aditama, Bandung.

Simamora, Henry, 2006. Manajemen Sumber Daya Manusia, Edisi Ketiga. STIE YKPN, Yogyakarta.

Sitohang, 2007. Manajemen Sumber Daya Manusia. PT. Pradnya Paramita, Jakarta.

Sugiarto dan Supramono, 2003. Statistika. Andi Offset, Yogyakarta.

Sugiyono, 2010. Statistika Untuk Penelitian. CV. Alfabeta, Bandung.

Sukandarrumidi, 2006. Metode Penelitian : Petunjuk Praktis Untuk Peneliti Pemula. Gadjah Mada University Press, Yogyakarta.

Tjiptono, Fandy, 2006. Pemasaran Jasa. Bayumedia Publishing, Malang.

Wardana, Weddy Kusuma, 2006. Pengaruh Pemberian Kompensasi Terhadap Motivasi dan Prestasi Kerja (Studi Kasus PT. Sasami di Solo). Skripsi Program S1 Fakultas Ekonomi UKSW, Salatiga.

Wibowo, Mukti, 2014. Pengaruh Lingkungan Kerja Terhadap Kepuasan Kerja Karyawan (Studi pada Karyawan PT.Telekomunikasi Indonesia Tbk. Kandatel Malang). Jurnal Administrasi Bisnis (JAB), Vol. 16 No. 1 (November 2014), 1-9. 